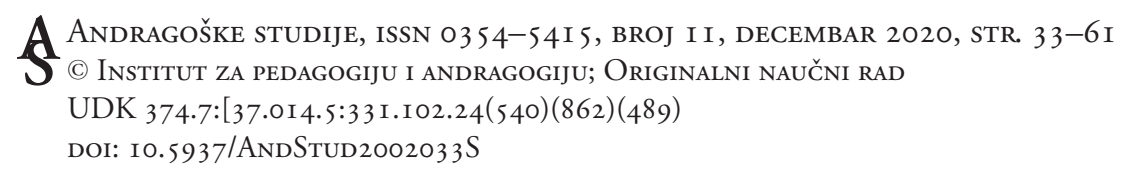

Shalini Singh ${ }^{1}$

Julius Maximilians University of Würzburg, Germany

Mario Molina-Naar ${ }^{2}$

University of Los Andes, Colombia

Søren Ehlers ${ }^{3}$

Julius Maximilians University of Würzburg, Germany

\title{
Policies for Professionalisation in Adult Learning and Education: A Comparative Study from India, Colombia and Denmark ${ }^{4}$
}

\begin{abstract}
This paper discusses the role of policies in promoting or hindering professionalisation in adult education in different contexts. The paper draws generalisations based on three case studies: India, Colombia and Denmark, where professionalisation of adult education is negligible. The methodology includes case studies, policy analysis and a comparative perspective. The paper concludes that the professionalisation of adult education has diminished with the emergence of lifelong learning because the focus of policies has shifted to learning outcomes rather than educators. Stakeholders who favour the professionalisation of adult education and learning, therefore need to ensure the development of distinctive offers, create a market for them and get them acknowledged to convince policy makers for investment.
\end{abstract}

Key words: professionalisation, standardisation in adult education, andragogy, policy, lifelong learning.

\footnotetext{
${ }^{1}$ Shalini Singh, $\mathrm{PhD}$ is Senior Research Fellow at the International Institute for Adult \& Lifelong Education, India and a visiting researcher and lecturer at the Julius Maximilians University of Würzburg, Germany (contactingshalinisingh@gmail.com).

${ }^{2}$ Mario Molina-Naar, is Full-Time Professor at the University of Los Andes, Colombia and a PhD candidate at the Autonomous University of Barcelona, Spain (molinaar712@gmail.com).

${ }^{3}$ Søren Ehlers, PhD is visiting researcher and lecturer at Julius Maximilians University of Würzburg, Germany and distinguished professor at International Institute for Adult \& Lifelong Education, India (soerenaugustehlers@gmail.com).

${ }^{4}$ The authors are thankful to our colleagues: Trudy Corrigan and Jane O' Kelly for their contributions in reviewing the literature.
} 


\section{Introduction}

Despite the increasing influence of learners, educators appear to make a significant difference in the education system. Professionalisation in adult learning and education has been identified as an indicator to estimate its quality (Egetenmeyer, Breitschwerdt, \& Lechner, 2018). Professionalisation is relevant for coping with the challenges of uncertainty and preparing adults for precarious jobs (Cervero, 2017). While most research is limited to individual attributes regarding the way an adult educator should or could teach (Lencer \& Strauch, 2019), some researchers argue that professionalisation in adult learning and education depends upon its competitiveness in the market (its demand in the market) and its capability to align itself with the regulations (moulding itself in accordance to policy guidelines and laws) that influence it (Noordegraaf, 2015; Egetenmeyer et al., 2018; Breitschwerdt, Lechner, \& Egetenmeyer, 2019).

Whereas the national focus on the professionalisation of adult educators is considerable in countries like Germany, it is almost absent in many others, like India and Colombia. In countries like Denmark, on the other hand, it appeared as a wave in the 1970s and faded away in the 1990s. Since national policies predominate the mobilisation of resources, they are one of the most relevant factors in determining the development of professionalisation. This paper explores the linkage between policy and professionalisation in adult learning and education in contrasting contexts. Professionalisation in this paper has two meanings: professionalisation of individuals (adult educators), which means equipping adult educators with standardised competencies for ensuring the production of a distinctive product by distinctive skills based on a special (only meant for adult educators) body of knowledge; and professionalisation of the field/sector, which implies specific occupational regulations and remuneration for adult educators that reflect the acknowledgement of their unique contribution to providing or facilitating adult education.

The research question for the paper is: How do national policies support (or hinder) professionalisation in a given context? The conceptual framework comprises the multi-level research perspective on professionalism in adult learning and education (Egetenmeyer et al., 2018). Using this perspective, the national policies on adult learning and education in India, Colombia and Denmark are examined in relation to professionalisation, first separately and then in comparison. All three cases apparently have limited or no professionalisation in adult education. Sources for research include relevant policy documents and contextual information along selected parameters. The methods thereby primarily include case studies and policy analysis, followed by a comparative perspective and ana- 
lytical approach to draw generalisations. Egetenmeyer et al.'s (2018) multilevel perspective on professionalisation of adult and continuing education is used as the conceptual framework. The paper discusses the adequacy of the perspective for analysing the three selected cases and for drawing generalisations from them.

\section{Review of the Existing Literature}

A profession can be characterised by common practice, a shared knowledge base, an ethical code of conduct determining the behaviour of the professionals, and control on the entry into the specified group of professionals (Benn and Fieldhouse's assertion (1994) in Doyle, Egetenmeyer, Singai, \& Devi, 2016). A professional delivers a distinctive product, gets specific training to produce it, and keeps control over the final product (Larson, 1977). In adult and continuing education, the term "professionalisation" has been used to indicate personal behaviour (for instance in the UK, Germany and India) as well as regulation and standardisation of the field, especially in favour of economic considerations (Doyle et al., 2016). At least in European policies, the change from the former to the latter has been widely reflected (Research voor Beleid [Alpine], 2008). However, in most cases, adult education has not necessarily been able to ensure professionalisation, except in academia (Cervero, 1992).

The "social reformist" and "professional" traditions in adult education have their own reasons to resist and support professionalisation, respectively (Cotton, 1964). Whereas the "social reformist tradition" banks upon idealism, morality and intellectual inputs for making lives better and striving towards an equal balance in society, the "professional tradition" disagrees (Cotton, 1964). The "professional tradition" favours idealism and morality, but rejects the utopianism of everything being for the good, and warns against the political orientations that might appear to be ideal but lack discipline and could be hijacked by political propaganda (Cotton, 1964). However, it is impossible to deny the negative consequences of professionalisation, which include its sometimes mechanical nature; a struggle for control over funding emanating from licensing, certification and/or accreditation; and the degeneration in the idealistic-moral elements, followed by the consequent loss of meaning of adult education itself (Collins, 1992; Cotton, 1964).

However, it has been claimed that the development of specific adult education programmes has answered the question about whether there should be professionalisation, and that the dichotomy between the social reformist tradition and the professional tradition is falsely framed and redundant (Cervero, 
2017). Further, it is argued that, since adult education is a critical component of knowledge and power balance in society, it cannot be handled unprofessionally (Cervero, 2017; Cervero \& Wilson, 2001; Cervero \& Wilson, 2006; Merriam, Courtenay, \& Cervero, 2006). Is this reflected in policies, too? This paper contributes to validating this argument using empirical sources (policy documents).

Societal, organisational and personnel factors influence the "new professionalism" (Egetenmeyer et al., 2018; Breitschwerdt et al., 2019). Individual adult educators (personnel factor) try to balance these three types of factors against each other (Breitschwerdt et al. 2019). The management (organisational factor) plays a crucial role in defining professional norms as well as developing strategies for professionalisation in order to deliver according to the set standards (Evetts, 2011). Professionals do not necessarily follow the market demand (logic of market) or behave in accordance with the criteria set by the organisations (organisational logic) they work with (Freidson, 2001). Professionals have their own logic (the third logic, as Freidson (2001) calls it), emanating from the nature and scope of the adult education profession itself. However, this logic is increasingly becoming subservient to "managerialism" (organisational logic) and "commercialism" (market logic), thereby diminishing the presence of professional logic in the work performed (Evetts, 2011). "Hybrid professionalism", or maintaining a balance among the three logics, is a major challenge for professionals in the field (Nordgraaf, 2015; Breitschwerdt et al., 2019). There is a lot of research on what is conceptually defined as professional in adult education and learning, but that research has found only limited reflection in policies. Further, professionalisation in adult education has been criticised for a narrow emphasis on profitability and economic value, especially in response to precarious jobs (Hughes \& Tight, 1995; Lynch, 2010; O’Neill \& Cullinane, 2017). This paper contributes to our understanding of the necessary elements for professionalisation to inform policies and reflects on the possibilities for establishing a balance between professionalisation, managerialism and commercialism.

It is argued in academic literature that the policy focus on lifelong learning and the need for social development and cohesion have created the need for professionalisation (Andersson, Köpsen, Larson, \& Milana, 2012; EC, 2006, 2007a, 2007b; Merriam \& Brockett, 2007; Nuissl \& Lattke, 2008; Cervero, 2017). Apart from this, the predominance of global competitiveness and economic considerations put forth by policy makers have further added to the relevance of professionalisation in the field (just like in other areas of education) by treating adult and continuing education as a commodity and promoting its marketisation (Spring, 1998; Apple, 2006; Robinson, 2016 cited in O’Brien, 2018; Smith \& O'Leary, 2013; Fejes \& Olesen, 2016; Yasukawa \& Black, 2016 cited in O’Brien, 
2018, p. 557). The paper validates this claim on the basis of case studies, analysing whether the shift from adult education to lifelong learning has created a space for professionalisation in reality.

Despite the existence of a wide variety of pathways for professionalisation in the field (Andersson et al., 2012), reflecting the diverse nature of adult education and lifelong learning (Buiskool, Lakerveld, \& Broek, 2009; Research voor Beleid/PLATO, 2008), a trend towards standardisation of how professionalisation should be done has emerged, at least in Europe, through the Bologna Declaration (1999), the Copenhagen Declaration (2002), the Treaty of Lisbon (2009) and the New Skills Agenda for Europe (2016) (Cieslak, Ricardo, Fehrenbacher, Praveen, \& Nierobisch, 2017; Buiskool, Broek, van Lakerveld, Zarifis, \& Osborne, 2010). However, differences still remain in relation to the characteristics and functions associated with adult educators in different contexts within and beyond Europe, which influence the "competence profiles" of adult educators (Ciselack et al., 2017; Buiskool et al., 2010). The paper also analyses this contradiction through the cases.

The Cases of India, Colombia and Denmark: It is important to note that the level of professionalisation in adult education is negligible in the three selected cases: India, Colombia and Denmark. In the case of India, adult education is implemented as a mission. The sector is characterised by a large number of nonliterate and semi-literate people (about 313 million in 2017), limited resources (especially funding) and the consequent need for voluntary work (provided by NGOs or professionals in other fields), low level of skills imparted (basic and functional literacy, sometimes limited vocational skills like sewing) through adult education programmes, limited political will and limited research in the area (Shah, 2008, 2010, 2013; Kuhlen, Singh, \& Tomei, 2016; Singh \& Assigner, 2016; Singh \& Sharma, 2016). Despite the availability of structured programmes for training adult educators, these programmes are not mandatory for the voluntary sector, and the quality of existing programmes is poor (Shah, 2008, 2010, 2013; Kuhlen et al., 2016; Singh \& Assigner, 2016; Singh \& Sharma, 2016).

In the case of Denmark, the professionalisation of adult education and educators was debated until 2000 (Rasmussen, Larson, \& Cort, 2019). However, the adoption of a 10-point programme by the Danish Parliament in 2000 (proposed since 1995) and the introduction of the Danish Lifelong Learning policy ended this debate (Larson \& Milana, 2011; Andersson et al., 2012; Rasmussen et al., 2019). The status of adult education as a sector ended with this, because all educational providers that had offers for the young were expected to provide learning opportunities for adults, too (Larson \& Milana, 2011; Andersson et al., 2012; Rasmussen et al., 2019). Usually, adult educators are professionals in other 
fields, meaning their professionalisation in the field is neither recognised as necessary nor viable anymore (Larson \& Milana, 2011; Andersson et al., 2012; Rasmussen et al., 2019). Moreover, the policy focus on learning has moved the thrust of all kinds of initiatives towards learning through any means possible rather than limited to any specific procedure or guidelines which professional adult educators may need to follow (Larson \& Milana, 2011; Andersson et al., 2012; Rasmussen et al., 2019; Ehlers, 2019).

In the case of Colombia, education has been a priority since the new constitution of 1991 (Cabrera Rosero \& Alfonso Caicedo, 2017), and adult education has been a major driver of socio-economic growth in this country. Despite this, the professionalisation of the field has not yet been addressed in the literature. There are probably two main reasons for this: first, the issue has not been advocated in education policies thus far; second, adult educators are professionals from different fields. In fact, there are currently no graduate programmes or official certifications for the professionalisation of adult educators. Recently, scholars and educators have advocated for adult education programmes, claiming that adult education is an "imported product" that is "far from the reality that students live" (Gomez 2019, as cited in Grillo, 2019). They propose the professionalisation of adult education programmes that specifically address the needs of this student population (Posada Escobar, 2020). Although these programmes would most likely be professional and not just occupational, their incorporation may create barriers for those who want to enter the field, and the national government might not be willing to take on another issue or responsibility related to adult education in the country.

The existing literature, therefore, provides a rich overview of the different aspects of professionalisation, the factors influencing it, and the subservience of professional logic to the marketisation and commodification of education, including adult and continuing education. However, the linkage between the economy and its impact on macro-level changes in cultural values, which may further reinforce or diminish the need for professionalisation, are not adequately explored. Despite the fact that policy studies are embedded and/or closely connected with the discipline of political science, there is limited literature which analyses policies for (or against) professionalisation with that perspective. Egetenmeyer et al.'s (2018) analysis seems quite convincing (see section on Conceptual Framework) and reflective of contemporary changes, but more empirical research is needed to validate it. Therefore, in order to enrich the knowledge base, there is a need to explore and verify the generalisations with a multidisciplinary approach (since Egetenmeyer et al.'s approach is primarily rooted in sociology), using case studies representing contexts different from the one in which Egetenmeyer et al.'s 
generalisations are embedded. The paper thus contributes to the existing literature by analysing the existing scientific considerations and making new additions to the knowledge base through case studies and multidisciplinary perspectives.

\section{Conceptual Framework}

The conceptual framework for this article is primarily comprised of the multilevel perspective on the professionalisation of adult and continuing education proposed by Egetenmeyer et al. (2018) and the power-interest matrix for stakeholder analysis (Johnson \& Scholes, 1999, as cited in Olander \& Landin, 2005).

Egetenmeyer et al. (2018) argue that professionalisation is influenced by factors at three different and interdependent levels: personnel, organisational and societal. Personnel factors comprise individual behaviour; organisational factors comprise provider activity (or non-activity), and societal aspects include the positioning of adult and continuing education as a profession in society, characterised by law, policies, social acceptance and the like (Egetenmeyer et al. 2018).

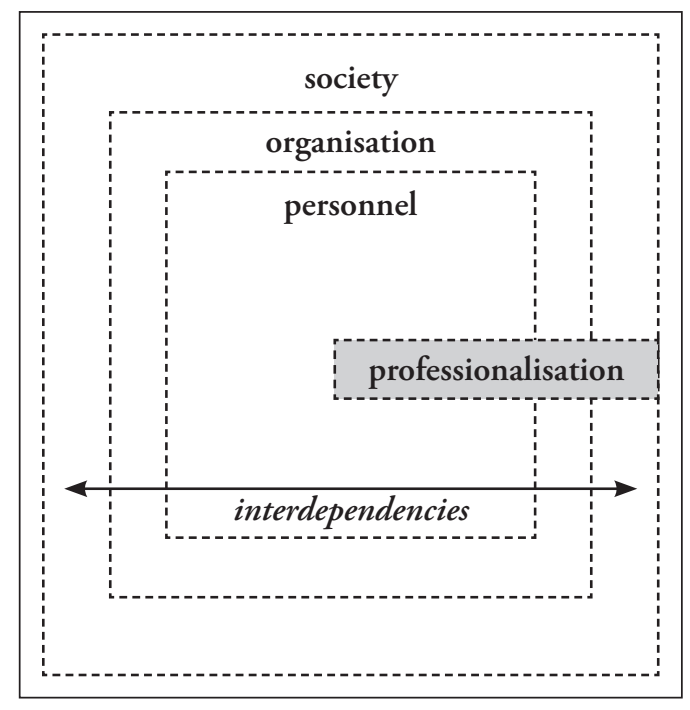

Figure 1. Interdependencies of professionalisation in adult and continuing education (Source: Egetenmeyer et al. 2018, p. 13)

The perspective implies that favourable/ unfavourable changes and situations at one level might lead to changes in favour of or against professionalisation at other levels and in the entire system. In the current paper, this model is 
used to analyse how these interdependencies are addressed through policies in different contexts.

The conceptualisations by Egetenmeyer et al. (2018) are rooted primarily in the sociological approach. However, the primary sources for this paper are policies (understood as compromises among stakeholders). To analyse them adequately, we have therefore complemented Egetenmeyer at al.'s approach with stakeholder analysis based on the power-interest matrix (Mendelow, 1981; Johnson \& Scholes, 1999, as cited in Olander \& Landin, 2005).

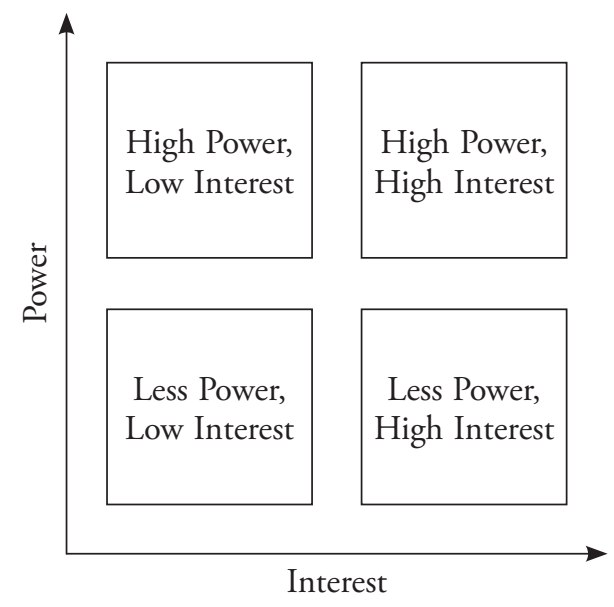

Figure 2. Stakeholder Analysis: Power-Interest Matrix (Source: Illustration by authors adapted from Olander and Landin, 2005)

The power-interest matrix suggests that stakeholders (actors with directly or indirectly involved benefits and losses) with relatively more power and high interest influence the policy process the most and vice versa.

\section{Case Studies}

\section{India}

India is a lower-middle income, highly populated country with more than 1.35 billion people of a median age of around 29.4 years (in 2018, c.f. Worldometer, n.d.). The literacy rate in India was around 74.4 per cent (in 2018, c.f. UNESCO, n.d.) with very high unemployment (around 6.6 per cent in November 2020) and up to around 200 million underemployed persons engaged in 
low-income, low-productivity jobs (35 to 40 per cent of the total 540 million employed in 2020) (Centre for Monitoring Indian Economy, 2020). Complementing the steep decline in the economy, the rate of employment has been constantly falling to the lowest in the last 45 years (Government of India, 2019). The education of adults, therefore, is key to survival - and insight also stated in the Indian policy.

Access to education is not only relevant for economic development but also necessary for dealing with social problems, especially in relation to social stratification (caste system) ${ }^{5}$, marginalisation, inequality and gender disparities (Department of School Education and Literacy, n.d.). Basic education has been a right in India since 2009 (Ministry of Law and Justice, 2009), but it is neither compulsory nor accessible or adequately funded (OECD, n.d.). As a consequence, more than 313 million adults are non-literate, and about 59 per cent of them are women (Chandra, 2019). 88.6 per cent of the employment in India was informal in 2018 (International Labour Organisation, n.d.; Ministry of Statistics and Programme Implementation, n.d.).

In such a context, basic as well as functional literacy have been the priority of adult education programmes, especially for the marginalised, among them women, even though programmes have extended beyond that (Department of School Education and Literacy, n.d.). Policies in the past have focussed on quantity rather than quality, and the data are estimates (based on samples/extrapolation) rather than accurate figures (Department of School Education and Literacy, n.d.; Ministry of Human Resource and Development, 2020).

Adult education has been primarily measured in terms of basic literacy and numeracy, even though additional offers for localised economic survival, like simple farming techniques and sewing, have existed as well (Department of School Education and Literacy, n.d.). Most of such offers are now part of the voluntary sector, and the policy provisions do not include them as parameters to measure or evaluate the status of adult education systematically. Unlike in many other countries, basic and sometimes advanced skill development programmes regulated by policy in India are categorised as skill development (governed by a dedicated Ministry for Skill Development and Entrepreneurship) rather than adult education. Similarly, adult learning occurring in formal, non-formal or informal settings for work in private and voluntary sectors, recreation or any other purpose is kept clearly out of the policy on adult education. In other words, even though the policy claims to reconfigure the education system and align it according to the United Nation's Sustainable Development Goal 4 (to which India is a

\footnotetext{
${ }^{5}$ A system of social stratification in India that categorises people by birth at present. It is a perverted form of
} Ancient Indian social stratification, which was made on the basis of profession, not birth. 
party), (Ministry of Human Resource and Development, 2020) lifelong learning is mentioned symbolically, and labour market policy is not integrated with adult education policy to ensure sustainable education. Skill development comes under a separate ministry, and adult learning in private and voluntary sector settings does not come under the adult education policy at all. It is notable that the policy on adult education keeps teaching and learning among adults in the voluntary and the private sectors out of its purview and does not recognise it under adult education (unlike in many other countries). Therefore, at the societal level, there is a gap in terms of reaching out to millions with limited resources and teaching them basic skills and knowledge, leading to social prestige and survival jobs.

The Indian policy, since the beginning, has banked upon the social reformist, volunteer-based approach and has gradually incorporated economic aspects in the past, even though it has never been completely economic in nature. The current policy on adult education marks a shift away from the gradual trend towards economic orientation (Ministry of Human Resource and Development, 2020). In its overall approach, the policy on education is cultural-social rather than socio-economic (as earlier) or primarily economic (as in many other countries). The policy is state led, issued by the Ministry of Human Resource and Development (proposed to be renamed as the Ministry of Education), guided by traditional Indian philosophy on education, and focussing on cultural attitudes and values rather than on economic competitiveness (Ministry of Human Resource and Development, 2020). The change in the name of the ministry also signifies a change from the economic (Ministry of Human Resource and Development) to the cultural approach (Ministry of Education, and as evident from parts of the document). Despite the fact that the influence of stakeholders from the private and the voluntary sector cannot be denied, the negotiations have neither been transparent nor acknowledged clearly in the policy document of 2020 (for details, see Ministry of Human Resource and Development, 2020).

The policy puts the focus on formal education (school and higher) while adult education is kept under "other key areas of focus" (Ministry of Human Resource and Development, 2020) despite the huge number of non-literate people, unemployed persons and those engaged in low-paid, low-productivity jobs.

The policy proposes an adult education curriculum framework (appearing to be an equivalency framework as per description) with foundational literacy, basic skills, critical life skills (or functional literacy and awareness regarding socially relevant issues like childcare and family welfare), vocational skills (for local employment like survival jobs), basic education (equivalent to primary and secondary education) and continuing education (in different areas like sports and culture) (Ministry of Human Resource and Development, 2020). Related 
programmes existed earlier, but the efforts seem to be clearly acknowledged and categorised now in 2020 .

Regarding the infrastructure, the existing dedicated adult education centres are supposed to be merged with an integrated infrastructure for educational purposes (Ministry of Human Resource and Development, 2020). School premises (after school hours or on weekends and holidays) are proposed as possible sites for adult education. Contrary to this, the policy states to build residential school complexes on traditional Indian education models (Ministry of Human Resource and Development, 2020). In that case, independent workspaces for adult educators are beyond imagination. Similarly, it is stated that the volunteers would be connected to local adult education centres by social workers or counsellors, but if there are no adult education centres, it is unclear where the volunteers are supposed to connect. These contradictory statements in the document imply that adult educators would not even be provided with their independent workspace and might need to struggle and work in uncertain conditions - not necessarily an attractive option for professionals.

Most adult and continuing education departments (which are the only source of formal degrees in adult education) offer limited opportunities to hire professional adult educators. Many of them were closed down or their funding was cut gradually (Shah, 2020; Government of India, 2018). In the private and the voluntary sectors, jobs for training and teaching adults require expertise in social work and other knowledge- or skill-specific content rather than the teaching of adults. In fact, adult education departments that give formal degrees in adult education that might lead to professionalisation do not necessarily hire professionals in adult education themselves (Shah, 2020). At the organisational level, the possibilities for professionalisation do exist, but they are not necessarily rewarding.

Given the current policy approach, the sector is not attractive in terms of returns on investment. The policy emphasises that volunteerism and mobilisation can lead to adult education (Ministry of Human Resource and Development, 2020). Adult educators are thus understood as trained volunteers who could mobilise and engage the masses in communities for adult education. The volunteers could be relatively educated people in the target communities or students in higher education institutions (Ministry of Human Resource and Development, 2020). The only possible professionals could be those working in different national, state- and district-level institutions such as higher education institutions, which would be responsible for training the volunteers. However, their qualifications or competencies are not specified either. This implies that the resource persons could be professional or unprofessional educators or experts in other fields, too (as is currently the case where educators from different fields are 
hired in adult education departments in higher education institutions without any specific and transparent criteria regarding their field-specific capabilities). Apart from these two types of human resources, the policy states to include social workers and counsellors (working independently, for the private sector under corporate social responsibility programmes or for the voluntary sector), who may support the volunteer adult educators or engage themselves as adult educators (Ministry of Human Resource and Development, 2020).

The provision for meagre monetary compensation for adult educators is replaced with non-monetary recognition for critical service to the nation (Ministry of Human Resource and Development, 2020). Training costs and arrangements for volunteers, as indicated in the policy, appear to be a responsibility of higher education institutions under extension and community outreach programmes (third mission of the higher education institutions apart from teaching and research), departments of social work or adult education and the like (Ministry of Human Resource and Development, 2020).

The available guidelines point clearly against professionalisation and towards volunteerism with basic working knowledge rather than professional expertise. Education costs in general, and professional education costs in particular, are borne by individuals owing to limited access to and the poor quality of publicly funded education. At the personnel level, attaining formal qualification in adult education is becoming more difficult, costly and increasingly irrelevant in terms of demand in the labour market.

The policy emphasises national integration and cultural preservation aside from economic (economic growth) and social aspects (social justice and equality) (Ministry of Human Resource and Development, 2020). The emphasis is on teaching rather than learning, and even though the policy mentions learning, the teacher is understood as one of the core elements in education (Ministry of Human Resource and Development, 2020). This does not create space for the professionalisation of adult educators with the existing approach in policy. Regarding the unregulated voluntary sector and private sector, the non-formal programmes (which do not provide formally recognised degrees or certifications) are tailored to the need of the organisation and usually executed by senior-level employees who are professionals usually in the field in which they teach. Further, given the huge unorganised labour market, where low-skilled, low-paid jobs predominate, highly sophisticated content is not a priority in adult education. Although reaching out to large numbers with limited resources can be a major opportunity for professionalisation, the overall policy approach in favour of volunteerism (where returns on professionalisation are limited) and value-based education (not necessarily shared by professional adult educators) hinders the process of professionalisation. 


\section{Colombia}

Colombia is a fast growing upper-middle income economy (WorldBank, 2019) and an OECD member state since 2020; it has a policy of compulsory education and, therefore, a high literacy rate of about 95 per cent (The World Bank Group, 2020). In the last few decades, Colombia has gone through a "silent" educational revolution (OECD, 2016a). The current Colombian policy divides the mainstream education system into four stages: early childhood education (0-6 years), basic education ( $7-14$ years), intermediate education (15-16 years), and higher education (17+ years) (OECD, 2016b). Higher education institutions generally offer two types of programmes: (1) academic programmes, which award a bachelor's degree, and (2) technical or technological programmes, which award a technical or technological degree. The latter can also be considered a type of adult education.

The academic programmes, or four-year bachelor's programmes, are offered by universities to prepare people for professional, or white-collar, jobs. The adult education programmes are offered by technological and technical institutions (two- or three-year vocational and technical programmes) to prepare people for technical or vocational jobs, also known as blue-collar jobs. Their objective is to ensure the employability of the population and the availability of adequate human resources with the required skills. Apart from that, the other category of adult education programmes, which are not part of higher education, are literacy programmes; they are meant for those who have remained non-literate or are school drop-outs. The proportion of such people is very low (only about 5 per cent of the country's population), but the state tries to bring them into the mainstream through the formal literacy programmes. In fact, as cited in the $3^{\text {rd }}$ GRALE Report published by the UNESCO Institute for Lifelong Learning in 2016, the current national development plan (2014-2018) attempts to eradicate illiteracy from Colombia; more specifically, it seeks to lower the illiteracy rate from 5.6 percent to 3.9 percent.

Regarding adult education, two types of educational offers can be categorised as such in Colombia: (1) technical and vocational educational programmes preparing people for traditionally working-class or blue-collar occupations, and (2) literacy programmes for school dropouts. Both offers are formal. After Colombia adopted a new constitution in 1991, all types of education were gradually formalised, and the government tried to ensure literacy for as many Colombians as possible. Non-formal education, therefore, was phased out.

In all kinds of educational programmes, including adult education programmes, educators need a bachelor's degree for teaching in their respective field. 
If specific skills are needed to teach a particular target group, they are provided through trainings and a required knowledge base by the institutions that offer such specialised programmes. Usually, such trainings for educators are paid for by the provider institutions. There are no general courses to become an adult educator. Despite the fact that all teachers are required to have a certification as a teacher or educator, it is not specifically mentioned that educators for adults and educators for children should have different qualifications. Their specialisation is in the field rather than in relation to the target groups they teach. Since those who teach adults teach a wide variety of subjects, they identify themselves more as certified in those fields rather than as adult educators.

The institutions which provide all sorts of educational offerings have the freedom to choose the requirements for the staff they want to hire. This is a part of the autonomous power granted by the Colombian Constitution of 1991 and the Law of Higher Education (1992), which mandate that these institutions operate under the principle of academic freedom. The law also grants faculty members freedom of teaching and research. In terms of quality, these institutions are obligated to follow the quality assurance guidelines laid down by the National Ministry of Education through the Law of Higher Education (1992).

The Colombian policy on adult education, thus does not explicitly mention the professionalisation of adult educators. Although there are provisions for the training of adult educators, it is neither obligatory nor necessary that such training be provided. In this way, the policies in Colombia do not touch upon the question of professionalising adult educators at all. In that sense, it can be said that the policy is indifferent towards professionalisation in adult education. However, it provides enough space and autonomy to providers of education, creating opportunities for the professionalisation of adult education in case it is needed.

\section{Denmark}

Denmark is a Nordic, high-income OECD member country with a 99 per cent literacy rate. Education for adults in Denmark was made completely formal in 2017. It applies to all types of educational offers for the adult population. Policies in Denmark no longer have provisions regarding professionalisation in adult education. However, this does not mean that professionalisation has never been meaningful in the Danish context. A chronological mapping of the policies in Denmark shows how the demand for andragogy and professionalisation in adult education appeared and vanished with contextual changes. Since the Nordic countries work in coordination with each other through the Nordic Council (a 
council of parliamentary members of all Nordic countries since 1955) and the Nordic Council of Ministers (a regional organisation of all Nordic countries since 1973), Danish policies regarding professionalisation had linkages to the policies of other Nordic countries, especially Sweden and Norway. Whereas the Danish and Norwegian approaches towards adult education have been predominantly non-formal, the Swedish approach has been rather formal. The evolution and decline of professionalisation of adult education in Denmark can be broadly divided into five different phases, based on the nature of activities, events and the relation of policies to professionalisation. References to relevant policies from Nordic countries and the Nordic Council of Ministers and events have been made wherever necessary to understand the Danish context.

Phase I: Adult education policies in the contemporary sense mentioned adult education for the first time in 1814 . The royal regulations for primary schooling of 1814 extended the right to basic education to youth and adults. Consequently, non-formal evening classes began in public schools for adults, with school teachers teaching both youth and adults (Ehlers, 2009).

Phase II: Since 1849, the first Danish Constitution has given its citizens the right to establish associations. Consequently, a number of associations sprang up to provide education for youth and adults. The activities, however, remained non-formal and did not receive any funding from the state. Although the state gradually contributed to organising adult education initiatives beginning in 1895 , there was no funding provided by the state for any kind of training or professionalisation for adult educators (Ehlers, 2009).

Apart from these associations, folk high schools for youth and adults (boarding schools) also provided non-formal education offerings. They were partly funded by the state and had the right to hire educators without any professional or even formal education. The philosophy of adult education initiatives in that period was influenced by Grundtvig's ${ }^{6}$ ideas, which emphasised freedom in educational affairs and favoured non-formal and informal approaches to adult education.

Phase III: The post-World War II period was characterised by more ambitious educational associations at both local and national level. These publiclyfunded associations offered adult education courses in non-traditional subjects. Thus, traditionally and formally trained adult educators had no place. Despite public funding, these associations were politically motivated in most cases; hence the staff they hired was rather political. Apart from that, skills that enabled people to perform simpler tasks such as sewing and food processing did not require a

\footnotetext{
${ }^{6}$ A famous Danish philosopher, politician and social reformer who played a crucial role in shaping non-formal
} education in Denmark (1783-1872). 
very high level of professional education and formal degrees and were imparted by part-time educators who had practical experience or skills rather than an andragogical background or special training to educate adults. The regulations regarding adult education were revised by the Danish Parliament in 1948, 1954 and 1960 (Ehlers, 2009), but the provisions in relation to professionalisation did not change.

In 1958, the first textbook about andragogy, and hence a relevant publication in relation to the professional behaviour of adult educators, was published in Sweden and Denmark. Research-based publications in Norway and Sweden followed (Ehlers, 2019). In 1961, the Nordic Council recommended that a Nordic institution for developing andragogy and conducting training programmes for adult educators be established (Nordisk Råd, 1961). In 1963, the Nordic Cultural Commission published a study about Nordic Cooperation in the field of adult education (Nordisk Kulturkommission, 1963).

Phase IV: The issue of professionalising adult educators in Nordic Countries was discussed in Oslo at a Nordic Conference in 1965, and references were made to the existing research and empirical data in the field. The Conference was followed by the establishment of the Nordic Folk Academy in 1966 in Sweden (Ehlers, 2009). The efforts for the professionalisation of adult education by Nordic countries were not limited to the Nordic region but extended to Europe. Policy papers released by the Council of Europe in relation to the professionalisation of adult education were written by Nordic experts in the field during that period (for instance, see Jessup, 1966)

In Denmark, the government published recommendations and regulations regarding a non-formal training programme for adult educators (along with a curriculum for the same) as part of its policy on adult education in 1965. Following the Swedish and Finnish model of professorships in adult education, the Danish government argued for a professorship in andragogy (Undervisningsministeriet, 1965). In 1968, the Danish government introduced the Act on Leisure Education for Adults. As a result, a wide variety of non-formal education offers funded by municipalities were provided. In 1970, Denmark established a professorship in andragogy (Ehlers, 2009). In 1973, a Nordic Conference regarding the development of andragogy was organised (Direktoratet for Ungdomsundervisning, 1973). Thus, the developments towards professionalisation in Denmark benefitted from favourable policies and research not only within the country but rather throughout the Nordic region.

In 1970, a merger in Danish municipalities and counties resulted in an increase in public support for non-formal education. In order to follow-up with the adult education initiatives, the Danish government appointed consultants 
(unlike inspectors in Sweden) at the national and county level along with local advisory councils at the municipal level. They were appointed to support adult education initiatives and had primarily non-formal education backgrounds. The county consultants and national educational associations organised state-funded, voluntary, non-formal training programmes with competitive offers for adult educators. The public consultants for adult education were abolished in 1990 because their mission was accomplished (Ehlers, 2009).

Within a decade (1972-82), non-formal education in Denmark developed into a sector. Following the UNESCO World Conference on Adult Education in Tokyo in 1972, the Danish Ministry of Education established several nationalsector councils in 1973 to cover all areas of education. Further, a Directorate for Folkeoplysning (non-formal education) was established in 1982 (Ehlers, 2009).

Phase V: In 1984, the Danish Parliament asserted that the real-world competencies of adult educators in relation to their field and pedagogy were to be given more weight than their formal qualification (10 Point Programme for Voksenundervisning og Folkeoplysning).

The Development Centre, a state-funded national institution for the innovation and development of formal and non-formal education of adults was established in 1985. In 1988, 1990 and 1998, the Parliament introduced policy changes and replaced the term Leisure Education with the broader term Folkeoplysning (non-formal learning). It augmented the freedom of local providers in relation to the professionalisation of adult educators and, in contrast, reduced the influence of the Directorate for Folkeoplysning. In 1990, a union of adult educators was established, but it did not focus on the issue of professionalisation (Kandrup, 2013).

In 1995, the Ministry of Education dropped the focus on non-formal education and argued in favour of formal part-time offers for adults with labour market experience (Undervisningsministeriet, 1995). The educators in the formal sector were already following guidelines in relation to professionalisation, which is probably why no reference to the same was made in the document.

Phase VI: In 2000, the Danish Parliament adopted the Further Education System. In 2002, the funding for Folkeoplysning was reduced (Kandrup, 2013), the Directorate for Folkeoplysning was abolished, and the Development Centre was closed. The policy of having a special sector for the non-formal education of adults was given up as well. In 2004, the Nordic Folk Academy in Gothenburg was closed by the Nordic Council of Ministers (Ehlers, 2009).

In 2005 , social partners ${ }^{7}$ were invited to discuss a strategy of globalisation, including discussions about various sectors of education. Neither professionali-

\footnotetext{
7 Social partners include employers and unions.
} 
sation in adult education nor in andragogy was proposed by the social partners despite detailed discussions about education for adults (Regeringen, 2006). In 2010, the Parliament narrowed down the scope of non-formal education, and in 2011, moved it from the Ministry of Education to the Ministry of Culture (Kandrup, 2013).

Over a decade (2007-17), the social partners and the government planned, adopted, and implemented fundamental changes in the education of adults and decided to make it completely formal in 2017 (Rasmussen et al. 2019).

A mapping of policies in Denmark thus shows that the formalisation of education (including the move from non-formal to formal adult education) reduced the possibility for the professionalisation of adult education in Denmark. Since professional standards already existed for all educators in the formal education sector (not specific to adult educators), the question of specific professionalisation in adult education is no longer debated in Denmark anymore. Further, the needs of adults (target groups) are so specific that is it extremely difficult and not necessarily rewarding to develop professional standards in adult education.

\section{Analysis of Cases and Comparison}

In all three cases, the absence of professionalisation in adult education (in relation to both educators and the field) is a consequence of different contextual factors. In the case of Denmark, the need for professionalisation faded away as the focus of education policy moved from teachers (or adult educators) to learners. With the adoption of lifelong learning and learning outcomes, what matters is the outcome in terms of learning rather than the educators, their working conditions, their offerings, or the distinctiveness of their contribution. The same applies to adult learning outside the policy purview in India in the private and the voluntary sector and in Colombia. While both Denmark and Colombia have professional standards for educators in general, providers are free to decide upon the kind of professionalisation they need for the educators. As a norm in Colombia, all educators need to have a professional teaching degree in the subject they teach irrespective of the target groups (children, adults etc.) they teach. In Denmark, owing to the tradition of non-formal education of adults, there are no formal barriers to becoming adult educators. In the case of India, no such requirements exist. In India, adult education is so narrowly included in the education policy that a huge part of adult learning is left out and, thereby, cannot be regulated in favour of professional standards. In any case, the approach of the policy is not in favour of professionalisation. 
In all three cases, it is evident that adult education is not acknowledged as unique or special, the contribution of adult educators not as distinctive, and the knowledge base for the discipline/andragogy not as specific. Adult learners do not come together in a programme like children belonging to an age cohort but rather with a subject-specific interest or need. Likewise, each subject has to be delivered in a specific manner in most cases. Therefore, the costs of professionalisation, especially in adult education and learning, do not seem to be rewarding. In most cases, a specific identity as an adult educator does not matter, and professionals in other fields are generally preferred because of their subject-specific professionalisation. A double professionalisation (professionalisation in a subject as well as in teaching it to adults) is neither cost-effective, required, or necessarily rewarding in relation to the investments made, especially when individuals need to bear the costs, for instance, in India. Adult education programmes are not compulsory like school education, where educators might benefit from dual professionalisation.

The development of artificial intelligence for education and self-directed learning platforms have diminished the relevance of adult educators and weakened the claims for professionalisation. The effectiveness and quality of educational offers depends upon learning outcomes. Thus, professionalisation might be one quality indicator of how effective and efficient the teaching of adults can be, but it may not necessarily fit into every context.

\section{Discussion}

It is evident from the three cases that national policies do not support the specific professionalisation of adult education or of adult educators in India, Colombia and Denmark. In the case of Colombia, all educators need to have a professional degree in what they teach (content) as well as in teaching, irrespective of the target group they teach. There is nothing specific for adult educators. Colombia is in fact even more standardised than Denmark, where the Danish tradition of non-formal adult education has been strong and rooted in the social reformist tradition.

In the case of Denmark, there was a demand for professionalisation during a certain period of time, but it was given up due the transition from adult education (education as a social policy) to lifelong learning (education as an economic policy). At present, when Denmark has a very high rate of participation of adults in adult learning programmes, the role of the adult educator is limited to a facilitator, with the learner in the primary role. Most policies and programmes 
are oriented towards learning outcomes, which is why the role of the teacher is mitigated in relation to how the policies measure effectiveness of education in a given context (Ehlers, 2019; Singh \& Ehlers, 2020). Further, the facilitator tends to be a professional in a different field, making double professionalisation seem costly, irrelevant and out of the question. The choices of adult learners regarding their learning pathways are so wide that any standardisation of teaching methods has also become difficult and unrewarding. Given that adults need to be on the labour market as much as possible, learning, although rewarding, has to be confined to short periods and focus on content and self-directed learning. Adult educators might get opportunities for facilitation and content design (rather than preparation), but this is usually done without hiring a costly professional. A similar logic applies in Colombia, where training programmes are designed and offered by the providers, which are free to choose whether or not to train educators.

In the case of India, adult learning programmes outside the purview of national policy have limited scope for professionalisation because those who facilitate in such programmes are usually professionals in other fields. The scope for professional adult educators cannot be denied, but professionalisation in other fields is both necessary and more rewarding for educators. The private and the voluntary sectors are not bound to hire professional educators, and when they can do without, they would prefer doing so to reduce costs. Despite the fact that professionalisation indicates quality, it is clear in cases like India that quantity is the priority.

In cases like Colombia and Denmark, the standard quality parameters apply to all kinds of teaching. In both cases, the formalisation of all education played a major role in standardised regulations, and no specific professionalisation needs for adult educators were defined. In the case of India, policy favours volunteerism rather than professional behaviour. To merge the two is difficult, because the costs of professionalisation must usually be borne by the individual, but the returns are negligible in terms of monetary benefits. At universities and some other institutions that are expected to hire professionals, the standards are similar for all educators, making professionalisation in adult education unnecessary. Further, most adult educators do not necessarily need to deliver any distinctive product built upon a special knowledge base (especially drawn upon andragogy). It might not be appropriate to call the volunteer training programme professionalisation, because it does not meet most criteria. There are no specific qualifications, selection methods, formal professional degrees based on a specific body of knowledge, distinctive products, or restrictions for others to teach as adult educators. The earlier programmes also failed to meet the standards but were a way forward. In other words, the opportunity was missed, and now that 
adult learning occurs outside the purview of policies, policy regulations are not desired because the space is already occupied, and alternative ways have been found. In India at least, it is time for redefining the work adult educators need to do and reflect about what kind of professionalisation is really needed now. Neither is there any measurement whatsoever of what is delivered. Even though professionalisation involves several characteristics, the production of a distinctive product seems to be one of the most important ones. It can attract funding, create a space for professionalisation and ensure survival in a competitive environment. At the individual level, there are limited options for professionalisation; it has to be financed largely by the individual (adult educators), it does not have much monetary benefits, and hence returns on investment are very low. At the organisational level, departments that provide specialised degrees are being closed, the quality of research is poor, and resources are limited. It is neither a priority for governments nor a priority for providers. At the societal level, there is a need for both adult education and professionalisation to design effective and efficient outreach programmes, but the stakeholders have limited influence on policy and the learners usually get adult education as a free benefit, which is why they cannot complain. With limited resources, they are bound to accept whatever they get.

The move from the socio-economic back to the cultural-social paradigm in India marks the move away from professionalisation and towards social-reformist, traditional adult education. Offering courses in the discipline of adult education or andragogy might be just one factor, but other factors like market demand, availability a distinctive product only on the basis of adult education and others challenge the professionalisation process.

Although the question of whether professionalisation should be pursued seems quite redundant in the literature, it is still very relevant in policies.

The multilevel perspective on the professionalisation of adult and continuing education (Egetenmeyer et al. 2018) facilitated the analysis and explained the interrelationship between different factors quite well. It is important to note that the interdependencies between different levels are embedded in a certain policy framework in each context, and that framework defines the nature of interdependencies and their extent. Thus, apart from analysing the interdependencies, it is fruitful to also analyse the policy framework. Each interdependency might lead to many possibilities, but these policies can be determined and defined by the policy framework in most cases. The logic of professionalisation seems different from the logic of the social reformist tradition. The difference was clearly reflected in the UNESCO World Conferences on Education in 1960 (predominated by the social reformist tradition and actors from the voluntary sector) and 1972 (predominated by the professional tradition, primarily bureaucrats educated in law) (Knoll, 2007). Pro- 
fessionalisation may challenge the possibility for one kind of value-based education or political propaganda inherent in the social-reformist tradition, but it might lead to another kind of value-based education or political propaganda. Therefore, the policy framework in which the policy is embedded is an important factor.

If policy makers leave professionalisation unregulated, it is difficult to get a balance, so political support is needed. Otherwise, researchers and adult educators need to make adult education attractive, or in other words, align it more with the market to show how many returns we can get. Professionalisation does not fit into the sustainability picture with the existing arguments.

The integration of all educational provisions and the non-existence of adult education as an educational sector leads to a decline in the scope for professionalisation. In such contexts, standardised norms for all educators based on what they teach (content) rather than who they teach are developed. The difference between formal and non-formal education of adults is that formal education is based on standardisation in relation to the content (the subject). It is difficult for the voluntary sector to deliver a standardised yet distinctive product.

Professionalisation can be a quality parameter but in many contexts, it is not necessarily desired because of the costs and contextual factors. In the context of lifelong learning (which places the learner and learning, irrespective of how and where it is done, at the centre of everything), carving out a role for adult educators and getting this funded appears to be only partially sustainable (not rewarding enough as compared to the investments made on it). Focussing on the individual needs of the learner is necessary if adult education programmes are to survive in the market, but at the same time, it leaves too little space for professionalisation and even andragogy to be standardised. When it comes to professionalising the education of adults with more regulations and provisions, the situation does not seem promising because of the trend towards standardisation, further integration of education with the labour market, growing individualisation in the needs of adult learners, and the centrality of learners rather than educators in the whole education process.

\section{Conclusion}

Policies are important to promote professionalisation, and professionalisation needs to be supported with regulations and resources. Offering a distinctive product based on special knowledge and maintaining the monopoly to create and deliver it are the most relevant criteria for professionalisation. The product should be convincing enough for individuals, providers and policy makers to fund it. 
Further, when the policy does not regulate, it becomes difficult to fund and ensure the availability of resources for professionalisation. When policies are not regulating, it has to be attractive for the market and the voluntary sectors by showing how it can increase productivity and contribute to their output. Without a clear distinctive contribution, professionalisation is not possible.

Despite all odds, professionalisation seems to be necessary for ensuring effective and efficient education and learning for adults. If adult education is to be used as political propaganda, professionalisation may or may not help. It might distance the educators from propaganda in favour of a certain value system, but at the same time, it may also enable adult educators to promote political aims in a more lethal and organised manner. Standardisation on the one hand, might help to facilitate learning, but on the other hand, it might lead to the creation of barriers for education or pathways for their exclusion from the mainstream.

With the integration of various sectors across qualification frameworks (from childhood to adult learning) and settings (formal, non-formal and informal), the shift of focus from teaching to learning (and learning outcomes), and the dissolution of adult education as a sector, and the occurrence of a major part of adult learning outside the purview of policies, the opportunities for professionalisation in adult education appear bleak unless it manages to offer, market and get acknowledged its output as a distinctive product, for which there is demand in the market and interest from policy makers so that they are convinced enough to invest in it.

\section{References}

Andersson, P., Köpsen, S., Larson, A., \& Milana, M. (2012). Qualification paths of adult educators in Sweden and Denmark. Studies in Continuing Education, 35(1), $1-17$.

Apple, M. W. (2006). Educating the "right" way markets, standards, god and inequality. Routledge: New York, NY.

Breitschwerdt, L., Lechner, R., \& Egetenmeyer, R. (2019). The "new professionalism" in adult and continuing education: A multi-level perspective. In The Good Adult Educator. Adult Education and Development, 86(16), 88-91.

Buiskool, B. J., Lakerveld, J., \& Broek, S. (2009). Educators at work in two sectors of adult and vocational education. European Journal of Education, 44(2), 145-162.

Buiskool, B. J., Broek, S. D., van Lakerveld, J. A., Zarifis, G. K., \& Osborne, M. (2010). Key competences for adult learning professionals. Contribution to the development of a reference framework of key competences for adult learning professionals. Project Report. Zoetermeer, Netherlands: Research voor Beleid. Retrieved from 
https://scholar.google.com/citations? user=eCJFN54AAAAJ\&hl=en\#d=gs_md_ cita-d \&u=\%2Fcitations\%3Fview_op\%3Dview_citation\%26hl\%3Den\%26use r\%3DeCJFN5 4AAAAJ\%26citation_for_view\%3DeCJFN54AAAAJ\%3AYsMS GLbcyi4C\%26tzom\%3D -60

Cabrera Rosero, M., \& Alfonso Caicedo, P. (2017). Educación formal de adultos en Colombia, una deuda pendiente. Tendencias y retos. Retrieved from http://www. colombiaaprende.edu.co/ckfinder/userfiles/files/Articulo_Educaci\%C 3\%B3n_ Formal_Adulto_Men_MC_PA.pdf

Centre for Monitoring Indian Economy. (2020). Unemployment in India. A statistical profile. May-August 2020. Retrieved from https://unemploymentinindia.cmie.com.

Cervero, R. M. (1992). Adult and continuing education should strive for professionalisation. New Directions for Adult and Continuing Education, 54, 45-50. https:// doi.org/10.1002/ace.36719925407

Cervero, R. M., \& Wilson, A. L. (2001). Power in practice: Adult education and the struggle for knowledge and power in society. San Francisco: Jossey-Bass.

Cervero, R. M., \& Wilson, A. L. (2006). Working the planning table: Negotiating democratically for adult, continuing, and workplace education. San Francisco: Jossey-Bass.

Cervero, R. M. (2017). Professionalisation for what? Fulfilling the promise of adult and continuing education. PAACE Journal of Lifelong Learning, 26, 1-20.

Chandra, T. (2019). Literacy in India: The gender and age dimension. ORF Issue Brief (322), October. Observer Research Foundation. Retrieved from https://www.orfonline.org/wp-content/uploads/2019/10/ORF_IssueBrief_322_Literacy-Gender-Age.pdf

Cieslak, C., Ricardo, R., Fehrenbacher, J., Praveen, B., \& Nierobisch, K. (2017). Between educating and teaching: The professional identity of adult educators. A transnational comparison between Portugal, India, and Germany. In R. Egetenmeyer \& M. Fedeli (Eds.), Adult education and work contexts: International perspectives and challenges from the 2017 Würzburg Winter School (pp. 143-160). Frankfurt am Main: Peter Lang.

Collins, M. (1992). Adult and continuing education should resist further professionalisation. New Directions for Adult and Continuing Education, 54, 37-43. https:// doi.org/10.1002/ace.36719925406

Cotтon, W. (1964). The challenge confronting American adult education. Adult Education, 14(2), 80-87.

Department of School Education and Literacy. (n.d.). Adult education: Overview. Retrieved from https://www.education.gov.in/en/adult-education

DireKTORATET FOR UNGDOMSUNDERVISNING. (1973). Voksenpadagogisk forskning og uddannelse. Rapport fra et arbejdsmøde den 4.-7. juni i Helsingør. København: Direktoratet for Ungdomsundervisning.

Doyle, L., Egetenmeyer, R., Singai, C., \& Devi, U. (2016). Professionalisation as development and as regulation: Adult education in Germany, the United Kingdom and India. International Review of Education, 62(3), 317-341. 
EC. (2006). Communication from the commission: Adult learning: It is never too late to learn. Brussels: Commission of the European Communities.

EC. (2007a). Action plan on adult learning: It is always a good time to learn. Brussels: Commission of the European Communities.

EC. (2007b). Communication from the commission to the council and the European parliament: Improving the quality of teacher education. Brussels: Commission of the European Communities.

Egetenmeyer, R., Breitschwerdt, L., \& Lechner, R. (2018). From "traditional professions" to "new professionalism": A multi-level perspective for analysing professionalisation in"adult and continuing education. Journal of Adult and Continuing Education, 25(1), 7-24. https://doi.org/10.1177/1477971418814009

EHLERs, S. (2009). Livslang læring som politisk strategi i 1900-tallets Danmark. Uddannelseshistorie, 44, pp. 28-54.

Ehlers, S. (2019). The rise of a learning regime in Europe. Transnational policy terms mapped and discussed. In T. Fristrup (Ed.), Socially engaged practices in museums and archives, Fornvårdaren 38 (pp. 17-68). Østersund: Jamtli Förlag.

EvetTs, J. (2011). A new professionalism? Challenges and opportunities. Current Sociology, 59(4), 406-422.

Fejes, A., \& Olesen, H. S. (2016). Editorial: Marketization and commodification of adult education. European Journal for Research on the Education and Learning of Adults, 7(2), 146-150.

Freidson, E. (2001). Professionalism: The third logic. Cambridge: Polity.

Government of India. (2018). Analysis of budget expenditure on education 2014-15 to 2016-17. Ministry of Human Resource and Development, Department of Higher Education. New Delhi. Retrieved from https:/www.education.gov.in/sites/upload_files/mhrd/files/statistics-new/ABE20 14-17.pdf

Government of India. (2019). Annual report 2017-18. Ministry of Statistics and Programme Implementation. Retrieved from https://www.google.com/urlsa=t\&sour ce=web\&rct=j\&url=http://mospi.nic.in/sites/default/files/publication_reports/ mospi_Annual_Report_2017- 18.pdf\&ved=2ahUKEwjstIGpgbHtAhVIA2MB HbbWA8UQFjAKegQIIBAB\&usg=AOvVaw2zcH8HXXYFA_eutCY5J0DR

Grillo, S. (2019, October 20). Colombia: Encuentro reunió a estudiantes, docentes y activistas para discutir la educación de personas jóvenes y adultas. Campaña latinoamericana por el derecho a la educación. Retrieved from https://redclade.org/noticias/ colombia-epja/

Hughes, C., \& Tight, M. (1995). The myth of the learning society. British Journal of Educational Studies, 43(3), 290-304.

International Labour Organisation. (n.d.). Statistics on the informal economy. Retrieved from https://ilostat.ilo.org/topics/informality/

Jessup, F.W. (1966). Workers in adult education. Their status, recruitment and professional training. Strassbourg: Council of Cultural Co-Operation of the Council of Europe.

Kandrup, P. (2013). Uden tvivl, med stort besvar. En historie om DOF 1973-2013. Helsingør: Dansk Oplysning Forbund. 
KnolL, J. (2007). The history of the international conferences on adult education: From Helsingør (1949) to Hamburg (1997): International education policy through people and programmes. Convergence, 40(3-4), 21-41.

Kuhlen, C., Singh, S., \& Tomei, N. (2016). The higher education curriculum for the professionalisation of adult education. In R. Egetenmeyer, S. Schmidt-Lauff, \& V. Boffo (Eds.), Adult learning and education in international contexts: Future challenges for its professionalisation. Comparative perspectives from the 2016 Würzburg Winter School (pp. 91-102). Frankfurt am Main: Peter Lang.

LARson, M. S. (1977). The rise of professionalism: A sociological analysis. Berkeley: University of California Press.

Larson, A., \& Milana, M. (2011). Professionalisation of adult educators in Denmark. International Journal of Continuing Education and Lifelong Learning, 3(2), 75-89.

Lencer, S., \& Strauch, A. (2019). GRETA - A competence model for teachers and trainers. The good adult educator. Adult Education and Development, 86(16), 76-80.

Law of Higher Education. (1992). Bogota, Colombia, 28 December 1992.

Lynch, K. (2010). Carelessness: A hidden doxa of higher education. Arts and Humanities in Higher Education: An International Journal of Theory, Research and Practice, 9(1), 54-67.

Mendelow, A. (1981). Setting corporate goals and measuring organizational effectiveness: A practical approach. Long Range Planning, 16(1), 70-76.

Merriam, S. B., \& Brockett, R. G. (2007). The profession and practice of adult education. San Francisco, CA: John Wiley \& Sons.

Merriam, S. B., Courtenay, B. C., \& Cervero, R. M. (2006). The role of adult education in addressing global issues. In S. B. Merriam, B. C. Courtenay \& R. M. Cervero (Eds.), Global issues and adult education: Perspectives from Latin America, Southern Africa, and the United States (pp. 485-496). San Francisco: Jossey-Bass.

Ministry of Human Resource and Development. (2020). National education policy 2020. Retrieved from https://www.education.gov.in/sites/upload_files/mhrd/ files/NEP_Final_English_0.pdf

Ministry of LAW AND Justice. (2009). The right of children to free and compulsory education act, 2009. No. 35 of 2009. The Gazette of India. Retrieved from https://www. education.gov.in/sites/upload_files/mhrd/files/upload_document/rte.pdf

Ministry of Statistics and Programme Implementation. (n.d.) Labour and employment statistics. Government of India. Retrieved from http://mospi.nic.in/94labour-and-employment-statistics

Noordegraaf, M. (2015). Hybrid professionalism and beyond: (New) Forms of public professionalism in changing organizational and societal contexts. Journal of Professions and Organization, 22, 187-206.

Nordisk Kulturkommission. (1963). Folkeopplysning i Norden. Av Brikt Jensen. Oslo: Nordisk Kulturkommission.

Nordisk RÅD. (1961). Betenkning vedr. Nordens Folkelige Akademi. Nordisk Udredningsserie. København: Nordisk Råd. 
Nuissl, E., \& LattKe, S. (Eds.). (2008). Qualifying adult learning professionals in Europe. Bielefeld: W. Bertelsmann.

O'Brien, T. (2018). Adult literacy organisers in Ireland resisting neoliberalism. Education + Training, 60(6), 556-568.

O’Neill, J., \& Cullinane, S. (2017). Holding the line: A slow movement towards a critical professional development for community educators. The Adult Learner: The Irish Journal of Adult and Community Education, 113-129.

OECD. (n.d.). Public spending on education. Retrieved from https://data.oecd.org/eduresource/public-spending-on-education.htm

OECD. (2016a). Education in Colombia. Highlights. Retrieved from http://www.oecd. org/education/school/Education-in-Colombia-Highlights.pdf

OECD. (2016b). Education in Colombia. Reviews of National Policies for Education. Paris: OECD Publishing. Retrieved from https://doi.org/10.1787/9789264250604-en.

Olander, S., \& Landin, A. (2005). Evaluation of stakeholder influence in the implementation of construction projects. International Journal of Project Management, 23(4), 321-328.

Posada Escobar, J. J. (2020). Notas para el análisis de las políticas públicas para laeducación de personas jóvenes y adultas (EPJA) en Colombia. In J. J. Posada Escobar \& B. C. Gómez López (Eds.), Por una educación de personas jóvenes y adultas emancipadora y garante de derechos: Encuentro de estudiantes de educación de personas jóvenes y adultas - EPJA (pp. 23-33). Coalición Colombiana Por El Derecho A La Educación - CCDE.

Rasmussen, P., Larson, A., \& Cort, P. (2019). The vocational turn of adult education in Denmark: An analysis of adult education policy from the late 1990s. International Journal of Lifelong Education, 38(3), 254-267.

Regeringen (2006). Denmark I Den Globale Økonomi. Konkurrenceevneredegørelse. København: Regeringen.

Research Voor Beleid/PLATO. (2008). ALPINE - Adult learning professions in Europe. A study of the current situation, trends and issues (Final report). Zoetermeer: Author. Retrieved from http://ec.europa.eu/education/moreinformation/doc/adultprofreport_en.pdf

Research voor Beleid. (2010). Key competences for adult learning professionals. Contribution to the development of a reference framework of key competences for adult learning professionals (Final report). Retrieved from http://www.frae.is/media/22268/ Kennarafaerni-2010_1168938254.pdf

Sнaн, S. Y. (2008). Funding adult education programmes in India: A study of policy, process, patterns and problems. Paulo Freire Memorial Lecture, 18-19 September 2008. New Delhi: Indian Adult Education Association.

Sнaн, S. Y. (2010). Teaching and training in adult and lifelong learning in India: Need for professionalisation. Retrieved from www.iaea-india.org/journal/oct-dec10/sy-shah. html. 
Sнан, S. Y. (2013). Challenges of professionalisation of adult education in India. [Conference (Revised) Paper]. International Conference of the European Society for Research on the Education of Adults \& ASEM 2013, Bonn, Germany.

ShaH, S. Y. (2020). How lifelong learning came to India. Online guest lecture on 21/06/2020. Writing for Research, Online Course by International Institute of Adult \& Lifelong Education.

Singh, S., \& Assigner, P. (2016). Policy and governance for the professionalisation of adult education. In R. Egetenmeyer, S. Schmidt-Lauff \& V. Boffo (Eds.), Adult learning and education in international contexts: Future challenges for its professionalisation. Comparative perspectives from the 2016 Würzburg Winter School. (pp. 53-64). Frankfurt am Main: Peter Lang.

Singh S., \& EHLERs, S. (2020). Employability as a global norm: Comparing transnational employability policies of OECD, ILO, World Bank Group, and UNESCO. In R. Egetenmeyer, V. Boffo \& S. Kröner (Eds.), International and comparative studies in adult and continuing education. (pp. 131-147). Florence: Firenze University Press.

Singh, S., \& Sharma, S. (2016). Professionalisation in adult education in India. International Journal of Research in Economics and Social Sciences, 6(11), 312-321.

Smith, R., \& O'Leary, M. (2013). New public management in an age of austerity: Knowledge and experience in further education. Journal of Educational Administration and History, 45(3), 244-266.

SPRING, J. (1998). Education and the rise of the global economy. Mahwah, NJ: Lawrence Erlbaum.

The World Bank Group. (2020). Literacy rate, adult total (\% of people ages 15 and above) - Colombia. Retrieved from https://data.worldbank.org/indicator/SE.ADT.LITR. ZS?locations=CO

UNDERVISNINGSMINISTERIET. (1995). 10-punktsplan om tilbagevendende THE RISE OF A LEARNING REGIME IN EUROPE EHLERS 61 uddannelse. København: Undervisningsministeriet.

UNESCO. (n.d.). Education system. India. Retrieved from http://uis.unesco.org/en/country/in

UNESCO INSTITUTE FOR LIFELONG LEARNING. (2016). $3^{\text {rd }}$ global report for adult learning and education. Hamburg: UNESCO Institute for Lifelong Learning.

World Bank. (2019). Data for Colombia, Upper middle income. Retrieved 15 December, 2019 from https://data.worldbank.org/?locations=CO-XT

Worldometer. (n.d.). India, population. Retrieved from https://www.worldometers. info/world-population/india-population/\#: : :text=\%2 0\%20\%201\%20The $\% 20$ current $\% 20$ population $\% 20$ of,of $\% 20$ countries $\% 20 \% 28$ an d $\% 20$ dependencies $\%$ 29\%20by\%20population.\%20More\%20 
Shalini Singh ${ }^{8}$

Univerzitet Julijus Maksimilijan u Vircburgu, Nemačka

Mario Molina-Naar ${ }^{9}$

Univerzitet u Los Andesu, Kolumbija

Søren Ehlers ${ }^{10}$

Univerzitet Julijus Maksimilijan u Vircburgu, Nemačka

\section{Politike za profesionalizaciju učenja i obrazovanja odraslih: uporedna studija iz Indije, Kolumbije i Danske ${ }^{11}$}

Apstrakt: U ovom radu se razmatra uloga politika u podstrekivanju ili usporavanju profesionalizacije u obrazovanju odraslih u različitim kontekstima. U radu se izvode generalizacije zasnovane na tri studije slučaja u Indiji, Kolumbiji i Danskoj, gde je profesionalizacija obrazovanja odraslih zanemarljiva. Metodologija obuhvata studiju slučaja, analizu politika i uporednu perspektivu. Zaključak je da je profesionalizacija obrazovanja odraslih manje zastupljena tokom celoživotnog učenja jer se fokus politika preusmerio na ishode učenja, a odmakao od samih edukatora. Akteri koji se zalažu za profesionalizaciju obrazovanja i učenja odraslih stoga moraju da osiguraju razvoj raznovrsnih i priznatih ponuda i da stvore adekvatno tržište za njih kako bi ubedili kreatore politike da ulažu u njega.

Ključne reči: profesionalizacija, standardizacija obrazovanja odraslih, andragogija, politika, celoživotno učenje.

\footnotetext{
${ }^{8}$ Dr Shalini Singh je viši naučni saradnik na Međunarodnom institutu za obrazovanje odraslih i celoživotno obrazovanje, Indija, i vanredni istraživač i predavač na Univerzitetu Julijus Maksimilijan u Vircburgu, Nemačka (contactingshalinisingh@gmail.com).

${ }^{9}$ Mario Molina-Naar je redovni profesor na Univerzitetu u Los Andesu, Kolumbija, i doktorand na Autonomnom univerzitetu u Barseloni, Španija (molinaar712@gmail.com).

${ }^{10}$ Dr Søren Ehlers je vanredni istraživač i predavač na Univerzitetu Julijus Maksimilijan u Vircburgu, Nemačka, i profesor na Međunarodnom institutu za obrazovanje odraslih i celoživotno obrazovanje, Indija (soerenaugustehlers@gmail.com).

${ }^{11}$ Autori rada su zahvalni kolegama Trudy Corrigan i Jane O’ Kelly na njihovom doprinosu pregledu literature.
} 